\title{
Factors Affecting Cyclist Behaviours in the Special Region of Yogyakarta
}

\author{
Danang Febrianto*, Dewanti, Imam Muthohar \\ Department of Civil and Environmental Engineering, Universitas Gadjah Mada, Yogyakarta, INDONESIA \\ Jalan Grafika No 2 Yogyakarta \\ *Corresponding authors: danangfbrnto@mail.ugm..ac.id
}

SUBMITTED 28 July 2021 REVISED 19 October 2021 ACCEPTED 26 October 2021

\begin{abstract}
Bicycle-riding/cycling has reportedly become a new trend in various cities of Indonesia, as well as the Special Region of Yogyakarta, amidst the social restriction applied by the Government to decrease the spreading rate of the COVID-19 virus. This is observed to be a healthier effort in strengthening the immune system during the pandemic. However, the positive growth of this trend is proportional to the increasing data on bicycle accidents. This was due to the increased rate of injured and dead victims from 2017 to 2020 . The human behavior factor is also one of the factors causing the high rate of these bicycle accidents. Therefore, this study aims to analyze the factors affecting the behavior of cyclists in the Special Region of Yogyakarta, to reduce the continuous increase of accidents. The data used in this study were the result of the Cyclist Behavior Questionnaire (CBQ) on the Yogyakarta riders. The samples were obtained through the purposive sampling method, using an online questionnaire with a google form and acquiring 362 respondents. Furthermore, the analytical method used was the structural equation modeling (SEM), through the AMOS 22.0 software. The results indicated that the regulation scale directly affected risk perception and cyclist behaviors (risky and positive). However, age only affected their behaviors, which did not directly affect the accidents. The regulation scale then directly affected the risky behavior of cyclists, with risk perception observed as the mediator, implying that the cyclists' knowledge of road safety regulations influenced individual behaviors. In conclusion, these results are expected to be one of the considerations in the policy of the government, to carry out the overall development of transportation, especially bicycles.
\end{abstract}

KEYWORDS Behavior; Cyclist; Traffic Safety; Structural Equation Modelling; AMOS.

(c) The Author(s) 2022. This article is distributed under a Creative Commons Attribution-ShareAlike 4.0 International license.

\section{INTRODUCTION}

The World Health Organization (WHO) reportedly determined that the Coronavirus Disease 2019 (COVID-19) was a new variant of an unknown virus on March $11^{\text {th }}$, 2020, which led to its declaration as a pandemic (World Health Organization, 2020). This caused the government to restrict mobility and traveling, as well as enforce the closure of school/business facilities, to accelerate the management of COVID-19 (Ministry of Health of RI, 2020). Amidst these social restrictions, a significant increase in the use of bicycles is being observed in Indonesia, especially the Specific Region of Yogyakarta (Yunianto, 2020). This location is popularly known as the city of bicycles, due to the increased previous and present use of these vehicles as a mode of transportation (Yogyakarta Government Tourism Office, 2019; Kompas.com, 2020). Besides the positive impact of this trend, a subsequent increase in the data of cyclist accidents within Indonesia has been observed (Bike to Work Indonesia, 2020), as shown in Figure 1.

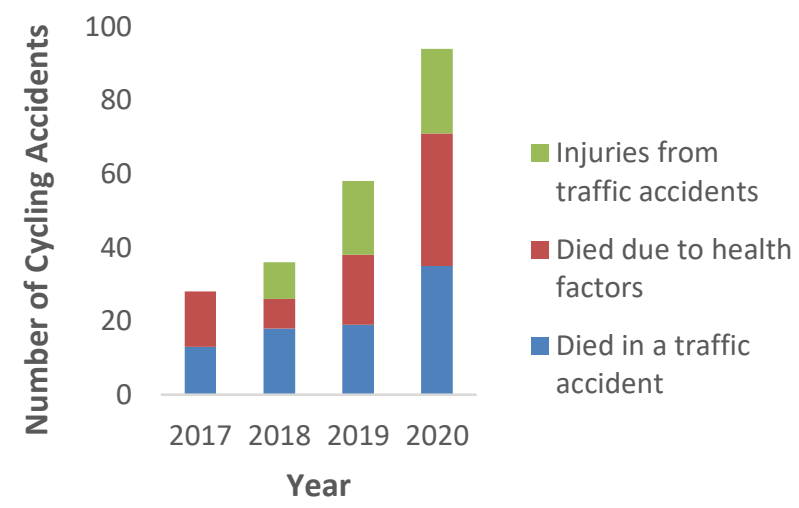

Figure 1. Cycling Accident Data in 2017-2020 (Bike to Work Indonesia, 2020) 
This indicates that further study is needed in increasing the safety behaviour of cyclists, which is one of the crucial aspects in improving precautionary measures (Arifin et al., 2018). Several previous studies have reportedly been conducted on bicycle-riding in Indonesia, based on the path designs and waiting rooms. However, only a few have focused on the factors affecting the safety behaviors of cyclists while on the road. Therefore, this present study is necessarily conducted based on supporting the safety of cyclists.

Several differences have also been observed between this study and previous ones. This includes the study on the behavior of cyclists, which is still very few in Indonesia. Due to the lack of sources, study experts are still in the stage of adopting questionnaires from similar foreign reports, with some character adjustments in Indonesia. Direct field observation is also being added in this study, with respondents' ages being limited to a minimum of 12 years. Furthermore, the analysis is being carried out using Excel, SPSS, and AMOS programs, respectively. Based on the previously described background, the high number of accidents is largely influenced by a cyclist's behavior, whose study is still observed to be very minimal. Therefore, this study aims to analyze the behavior of cyclists in Yogyakarta as an effort to support safety, to reduce the high rate of accidents.

\section{LITERATURE REVIEW}

\subsection{Cyclist Behaviour}

According to Arifin (2015), human behavior was the result of all kinds of environmental experiences and interactions, which were manifested in the form of knowledge, attitudes, and actions. The study of Useche (2018b) regarding the influence of gender on behavior also stated that age led to dangerous masculine characteristics, where young men are more likely to have risky driving attitudes than women. Meanwhile, the intense level of cycling affected both sexes. For risk perception, both genders had a significant effect on positive behavior. This indicated that higher risk perception led to a greater level of positive behavior. Based on Kummeneje (2020), risk perception was an important factor in the occurrence of conflicts when cycling, regarding the attitudes and perspectives of uncertainty among regular cyclists in Norway. This showed that an indivisual's attitude was directly proportional to the perception of risk. When this perception is poor, an attitude is likely to occur in the cycling skills of a bad rider. Besides these two factors, other indicators are also recognized, such as concerns, tolerance, and priorities, as well as the location of origin from the urban and rural areas.

\subsection{The Effect of Perception on Cyclist Behaviour}

According to Saputra (2017), the most dominant factor causing traffic accidents in Indonesia was humans or HR (human resources). Moreover, Kummeneje and Rundmo (2020), stated that in line with a safe driving attitude, the perceptions of risk and worry were sources of major concerns, as both were related to the risk-taking behavior of an individual. The study of Rundmo (1996), also explained that the relationship between perceptions, behaviors, and accidents, was a complex matter, indicating that there were at least 3 approaches to observe these associations, namely,

1. Accidents lead to the perception of risk,

2. Perceived risk lead to accidents,

3. Perception of risk and accident/safety are endogenous variables.

According to Lawson et al. (2013), the safety perception of cyclists in Dublin city was observed, where respondents cycled an average of 9.54 and $6.85 \mathrm{~km}$ on weekdays and weekends, respectively. The behavioral model of this study showed that the use of safety accessories was not related to the self-confidence of cyclists. This was because cyclists using these accessories were more obedient to the rules on the road. The compliance with these rules described the experience and confidence level of the cyclist, as the purpose of the trip was not related to safety. The results also showed that Dublin motorcyclists were very ignorant and careless on the aspect of safety. Although the perception of cyclists was divided 
into ages under and above 25 years, their use of safety accessories indicated that cycling was still dangerous than driving a car in Dublin. Also, the attitude of careless car drivers in this city was very risky. Therefore, the cycling experience affected the perception of safety.

\section{METHODS}

\subsection{Questionnaire Design}

The questionnaires that were digitally disseminated in the Indonesian language consisted of four sections.

Section 1: This contained individual and demographic variables, such as gender, age, occupation, and education.

Section 2: This consisted of self-reported risky cycling behavior, which used the raw data of the Cyclist Behavior Questionnaire (CBQ) (Useche et al., 2018c). The aspect of this questionnaire contained 44 items, which were divided into three factors through the Likert's Scale, namely Violations (V; 16 items), Errors (E; 16 items), and Positive Behaviors (PB; 12 items). Also, the total score of Risky Behavior was obtained from Violations and Errors (Useche dkk., 2018b). In addition, this questionnaire used five levels of scaling, namely $1=$ never, $2=$ rarely, $3=$ sometimes, $4=$ often, 5 = always.

Section 3: This encompassed the Cyclist Risk Perception and Regulation Scale (RPRS) used to measure the perception and knowledge of riders, regarding the policy of cycling. This consisted of 14 items ( 9 for perception and 5 for knowledge on regulation), where scales 1 and $5=$ the lowest and highest for the regulation knowledge/risk perception, respectively (Useche et al., 2018a).
Section 4: This included the cyclists' characters, to observe the aim of using bicycles, intensity, and experience on encountered accidents.

\subsection{Sample}

This study used online questionnaires through a google form, with the purposive sampling technique, which helped in selecting the target samples that conceived specific characteristics, based on the pre-determined criteria. Also, the use of online dissemination techniques considered the pandemic period limitations, to reduce direct interaction with other people. The selected respondents were cyclists with previous cycling experiences in the Special Region of Yogyakarta, the age range of these respondents was between 12 years old and above. This was because road cycling was not recommended for children below the age of 12 years (VicRoads, 2018). The respondent data recapitulation is shown in Table 1.

According to Sugiyono (2007), the minimum number of respondents used was 349 when the total population was uncertain. In this present study, 362 of 377 Yogyakarta cyclists filled the disseminated questionnaire after reducing the incomplete data. The results showed that 78 and $22 \%$ of these respondents were male and female, respectively. Furthermore, the cyclists between the age of 17-35 years dominated this study, with most being employees and students. The results also indicated that 70,29 , and $1 \%$ of the total population had higher, secondary, and elementary educations, respectively. In addition, $90 \%$ of the bicycles used were for sports, as $17 \%$ of the respondents reported that they had been in accidents. Based on age, the data on the respondents with accident experiences are shown in Table 3. 
Table 1. Data tabulation of gender vs respondent intensity vs age

\begin{tabular}{|c|c|c|c|c|c|c|c|c|c|}
\hline \multirow[b]{2}{*}{ Gender } & \multirow[b]{2}{*}{$\begin{array}{l}\text { Cycling } \\
\text { Intensity } \\
\text { (hours) }\end{array}$} & \multicolumn{7}{|c|}{ Age } & \multirow[b]{2}{*}{ Total } \\
\hline & & $\begin{array}{l}\text { Early } \\
\text { adolescence }\end{array}$ & $\begin{array}{l}\text { Late } \\
\text { adolescence }\end{array}$ & $\begin{array}{l}\text { Early } \\
\text { adulthood }\end{array}$ & $\begin{array}{l}\text { Late } \\
\text { adulthood }\end{array}$ & $\begin{array}{l}\text { Early } \\
\text { old } \\
\text { age }\end{array}$ & $\begin{array}{l}\text { Late } \\
\text { old } \\
\text { age }\end{array}$ & Elderly & \\
\hline \multirow{7}{*}{ Male } & $<1$ & 0 & 11 & 5 & 2 & 2 & 0 & 0 & 20 \\
\hline & $1-5$ & 0 & 49 & 44 & 21 & 6 & 5 & 3 & 128 \\
\hline & $6-10$ & 2 & 27 & 37 & 22 & 5 & 1 & 1 & 95 \\
\hline & $11-15$ & 0 & 9 & 9 & 6 & 1 & 1 & 1 & 27 \\
\hline & $16-20$ & 0 & 4 & 0 & 1 & 1 & 0 & 0 & 6 \\
\hline & $21-25$ & 0 & 0 & 2 & 1 & 0 & 0 & 0 & 3 \\
\hline & $>25$ & 0 & 1 & 3 & 0 & 0 & 0 & 0 & 4 \\
\hline Male total & & 2 & 101 & 100 & 53 & 15 & 7 & 5 & 283 \\
\hline \multirow{6}{*}{ Female } & $<1$ & & 7 & 2 & 1 & 1 & 0 & & 11 \\
\hline & $1-5$ & & 22 & 11 & 4 & 4 & 2 & & 43 \\
\hline & $6-10$ & & 11 & 2 & 3 & 2 & 0 & & 18 \\
\hline & $11-15$ & & 3 & 3 & 0 & 0 & 0 & & 6 \\
\hline & $16-20$ & & 0 & 0 & 1 & 0 & 0 & & 1 \\
\hline & $>25$ & & & & & & & & \\
\hline Female total & & & 43 & 18 & 9 & 7 & 2 & 0 & 79 \\
\hline
\end{tabular}

Table 2. Data tabulation of age vs accident vs cycling intensity

\begin{tabular}{|c|c|c|c|c|c|c|c|c|c|}
\hline \multirow{2}{*}{ Age } & \multirow{2}{*}{ Accident } & \multicolumn{7}{|c|}{ Intensity (hour/week) } & \multirow{2}{*}{ Tota } \\
\hline & & $<1$ & $1-5$ & $6-10$ & $11-15$ & $16-20$ & $21-25$ & $>25$ & \\
\hline Early adolescence & Yes & & & 2 & & & & & 2 \\
\hline $12-16$ years & No & & & 0 & & & & & 0 \\
\hline Late adolescence & Yes & 2 & 11 & 8 & 5 & 1 & & 0 & 27 \\
\hline $17-25$ years & No & 16 & 60 & 30 & 7 & 3 & & 1 & 117 \\
\hline Early adulthood & Yes & 0 & 8 & 8 & 6 & & 0 & 0 & 22 \\
\hline $26-35$ years & No & 7 & 47 & 31 & 6 & & 2 & 3 & 96 \\
\hline
\end{tabular}

Table 3. Continuation of data tabulation of age vs accident vs cycling intensity

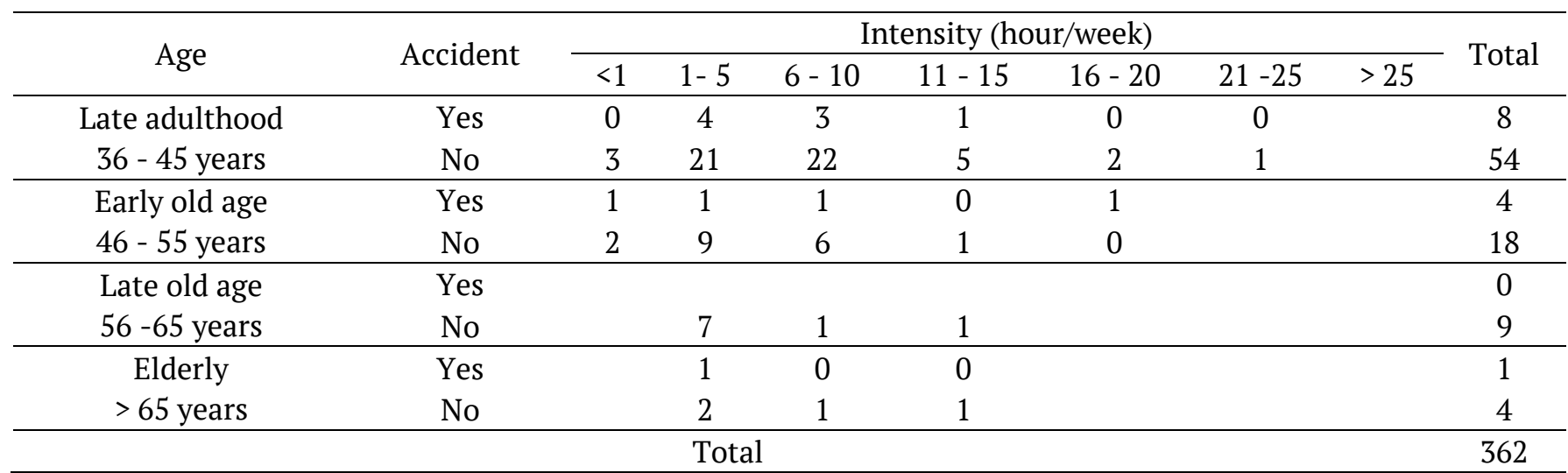




\subsection{Statical Analysis}

To observe the correlation effect among dimensions, the model testing was conducted through the Structural Equation Modelling (SEM), with the initial step using the Confirmatory Factor Analysis (CFA). This CFA test was performed to acquire the fit or significant variable to be used in the complete structural equation model. Also, the attempt to understand the latent variable eventually produced a conceptual definition known as a construct. This variable operational definition was created for the unobserved abstract construct to be measured through dimensions and indicators. Furthermore, the significance test was performed to empirically measure the previously tested latent variable. When the $p$-value $=\leqslant 0.05$ or C.R. $\geqslant 1.967$ (C.R. $=$ $\left.\mathrm{t}_{\text {count }}\right)$, the indicator or dimension was significantly determined, with continuity to the validity test. However, this indicator/dimension should be removed when the result is insignificant. The validity test was performed through the observation of the loading factor standard of each indicator or dimension. This indicated that when the standard is $\geqslant 0.5$, the result was validly determined. Meanwhile, the related indicator/dimension should be removed in the subsequent analysis when the result is invalid (Haryono, 2016).

The dimension reliability test used the CR (Construct Reliability) method, where assessments were carried out through the previously analyzed loading factor standard. According to the method, the score obtained from the analysis should be $\geqslant 0.7$ or acceptable between 0.6 - 0.7 (Hair Jr et al., 2010). A goodness of fit index test was also used to acquire a complete significant structural equation. Therefore, the assessments of statistical chi-square $\left(\mathrm{X}^{2}\right)$, significance probability (p), the goodness of fit index (GFI), Adjustment Goodness of fit index (AGFI), comparative fit index (CFI), Tucker-Lewis Index or non-normed fit index (TLI or NNFI), root mean square error of approximation (RMSEA), and root mean square residual (RMSR or RMR), were used to analyze the significance between the model and the data (Haryono, 2016).

\section{RESULTS}

The data analysis in this study was performed by examining each item, to determine when the results should be used as measuring instruments. Using the AMOS software, the validity test was conducted through convergent analysis. This indicated that the condition for the loading factor value stated that the score should be greater than 0.5. Moreover, reliability was tested by calculating the $C R$ value, with conditions stating that the acceptable score should be greater than 0.6 (Ghozali, 2008). After the data were validated by removing the insignificant loading factor values, the reliability test was carried out. Using the CR method, the values of the reliability test indicated the results greater than 0.6 , which were 0.9 and 0.7 each for risky and positive behaviors, as well as risk perception and regulation scale, respectively. After the dimension test using the CFA, the next analytical step was the formulation of the model structure.

This model was arranged from 3 exogenous variables, namely age, cycling intensity, and regulation knowledge (regulation scale). Also, the risk perception in this model functioned as the mediator, as three endogenous variables were observed, namely positive and risky behaviors, as well as accidents. The risky behavior variable was subsequently reflected by two factors, namely violations and errors. The indicator data in this model referred to previously analyzed information, through the confirmatory factor analysis. This showed that the loading factor values should be significant or greater than 0.5 and 0.6 in the validity and construct reliability tests, respectively. Therefore, each model was made as a unit and arranged according to the previously obtained theories. The initial GOF test showed a massive likelihood chi-square, as the significance values (p) were still insignificant, i.e., below 0.05 . The values of GFI, CFI, AGFI, and TLI were also yet to exhibit fit values, i.e., below 0.09 . Meanwhile, the RMSEA and RMR values were 0.056 and 0.321 , which were categorized decent 
due to being above 0.05. A fit structural model result was subsequently acquired after the modification indices stage, which was conducted by eliminating insignificant indicators based on the recommendation of AMOS. The chi-square value was categorized as good at 142.291 , which was lower than the $t$-table value (407.366). The significance value (p) of 0.384 was also categorized as good, due to being greater than 0.05. The GFI, AGFI, CFI, and TLI at 0.950, 0.932, 0.996 , and 0.996 respectively, were further found to be good based on exceeding 0.09 . In addition, the RMSEA and RMR values were good at 0.016 and $0.011 \leqslant 0.08$ and 0.05 , respectively. Using AMOS 22.0, Table 3 presented the direct effect of a construct towards others, while Table 2 showed the amount of the effect. With the standardized value of a coefficient parameter ( $p$ ) being below $\alpha=0.05$, the study hypothesis was supported by the data (significant) while the estimations showed the amount of effect. $p<0,05=$ significant

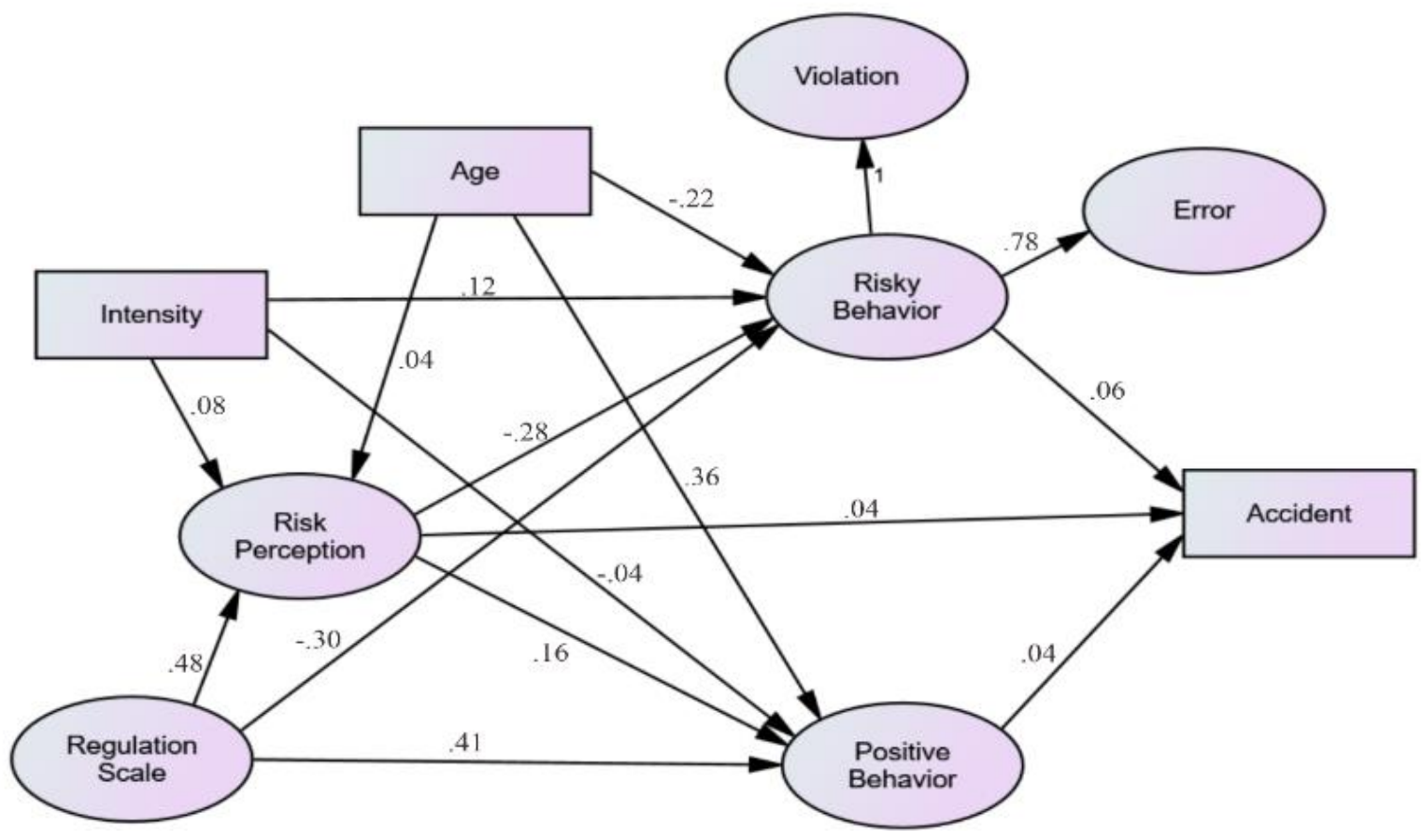

Figure 2. Standardized parameter estimates.

Table 4. Standardized direct effect

\begin{tabular}{lccccc}
\hline & Intensity & Age & $\begin{array}{c}\text { Regulation } \\
\text { Scale }\end{array}$ & $\begin{array}{c}\text { Risk } \\
\text { Perception }\end{array}$ & $\begin{array}{c}\text { Risky } \\
\text { behaviour }\end{array}$ \\
\hline Risk Perception & 0,081 & 0,040 & $\begin{array}{c}0,479 \\
(\mathrm{p}=* * *)\end{array}$ & \\
\hline Risky behaviour & 0,106 & $\begin{array}{c}-0,222 \\
(\mathrm{p}=* * *)\end{array}$ & $\begin{array}{c}-0,298 \\
(\mathrm{p}=0,004)\end{array}$ & $\begin{array}{c}-0,281 \\
(\mathrm{p}=0,002)\end{array}$ \\
\hline $\begin{array}{l}\text { Positive } \\
\text { behaviour }\end{array}$ & $-0,043$ & $\begin{array}{c}0,359 \\
(\mathrm{p}=* * *)\end{array}$ & $\begin{array}{c}0,411 \\
(\mathrm{p}=* * *)\end{array}$ & 0,115 \\
\hline Accident & & & 0,040 & 0,062 \\
\hline
\end{tabular}


The analytical results showed that age $(\mathrm{p}=0.529)$, intensity ( $p=0.177)$, and regulation knowledge of the cyclists (regulation scale) did not significantly affect risk perception. This was because the pvalue was still above 0.05 . However, the regulation knowledge positively affected risk perception at 0.479 . This indicated that better regulation knowledge highly affected cyclists. According to Kummeneje, et al. (2020), age had no significant effect on the risk perception of Norwegian cyclists. Meanwhile, Useche (2018b) stated that intensity had a significant influence on risk perception in Latin and North America, as well as Europe. This was not in line with the present study due to insignificant results. Differences in the study locations were likely to be a factor in these distinguished results. However, Useche (2018b) was in line with the study, based on having a significant positive effect on risk perception.

Based on the cyclists' risky behaviors, the results showed that the values of risk perception, age, and regulation knowledge (regulation scale) had significant and negative impacts at -0.281 , 0.222 , and -0.298 , respectively. This showed that better risk perception improved with age, leading to adequate safety regulation knowledge. These were in line with Useche (2018b), which showed significant results regarding the effects of age, risk perception, and regulatory knowledge, on the unsafe behavior of cyclists. However, different results were obtained on the intensity construct of both studies. This was because intensity had significant and insignificant $(p=0.088)$ effects on risky behavior, in Useche (2018b) and this present study, respectively. These results indicated that intensity level did not influence the risky behavior of cyclists. For positive behavior, no significant effect was observed with the values of risk perception and intensity at 0.411 and 0.359 , respectively. This was not in line with Useche (2018b), which stated that risk perception and intensity had a positive significant effect on the safety behavior of cyclists. However, similar results were observed for safety regulatory knowledge and age, which had a significant effect on positive behavior. This signified that good regulatory knowledge improved with older age, leading to a positive effect on road safety behaviors.

Based on the accident factor, significant impacts were not observed for the values of risk perception, as well as positive and risky behaviours. This was not in line with Useche (2018d), which showed significant results for both accident constructs. The low rate of accident victims among the respondents affected the results of this study, leading to the observed estimated differences with other reports. According to Table 4, the indirect relationship of the model was described using the Sobel Test method, to observe the significance value ( $p$ value). Several calculations were also performed using the Sobel Test Calculator (Preacher \& Leonardelli, 2010), which showed that only the regulation scale had a significant effect $(p=0.007)$ at -0.135 . This implies that the regulation scale affected risky behavior.

The better the regulatory knowledge of cyclists, the lesser the chances of exhibiting dangerous behaviors. The results obtained from this study should be a further recommendation in the decision-making policy of the government, which indirectly shows that safety regulatory knowledge influences dangerous behavior. This suggests that the government should continue to socialize and provide guidance regarding cyclists' road safety regulations, for them to be properly educated. Therefore, the recapitulation of the factors directly/indirectly affecting the behaviours of cyclists in Yogyakarta is shown in Table 6 as follows. 
Table 5. Standardized indirect effect

\begin{tabular}{llllll}
\hline & Intensity & Age & $\begin{array}{l}\text { Regulation } \\
\text { Scale }\end{array}$ & $\begin{array}{l}\text { Risk } \\
\text { Perception }\end{array}$ & $\begin{array}{l}\text { Risky } \\
\text { behaviour }\end{array}$ \\
\hline Risk Perception & & & $\begin{array}{l}\text { Positive } \\
\text { behaviour }\end{array}$ \\
\hline Risky behaviour & $-0,023$ & $-0,011$ & $\begin{array}{l}-0,135 \\
(\mathrm{p}=0,007)\end{array}$ & \\
\hline $\begin{array}{l}\text { Positive behaviour } \\
\text { Accident }\end{array}$ & 0,009 & 0,005 & 0,055 & \\
\hline
\end{tabular}

Table 6. Recapitulation of direct and indirect influences

\begin{tabular}{llllll}
\hline Effect & Factor & & & Value & Result \\
\hline \multirow{4}{*}{ Direct } & Risk perception & $<---$ & Regulation Scale & 0.479 & Significantly positive \\
\cline { 2 - 6 } & \multirow{2}{*}{ Risky behaviour } & $<---$ & Risk Perception & -0.281 & Significantly negative \\
& & $<---$ & Age & -0.222 & Significantly negative \\
& \multirow{2}{*}{ Positive behaviour } & $<---$ & Regulation Scale & -0.298 & Significantly negative \\
& & $<---$ & Age & 0.359 & Significantly positive \\
& & $<--$ & Regulation Scale & 0.411 & Significantly positive \\
\hline \multirow{2}{*}{ Indirect } & Risky behaviour & $<---$ & Regulation Scale & -0.013 & Significantly negative \\
\hline
\end{tabular}

\section{DISCUSSION}

The direct effect showed that the regulation scale directly and positively affected the perception of risk in behaving, indicating that a better understanding of safety led to a greater assessment of uncertainties. Also, the regulation scale affected both positive and risky behaviors (cyclist behaviours). In addition, this safety regulation indirectly and negatively affected risky behaviour, indicating that better knowledge of rules led to more negligence in unsafe behaviors. In this study, the regulation scale significantly contributed to risk perception and behaviour, indicating the concern to be addressed in making future policies. The socialization regarding safety rules and information should also be continuously conducted through the effectiveness of community forums, based on the existence of several bicycle utilization, such as sports equipment, regular use, hobby, short-

\section{CONCLUSION}

The use of bicycles as a tool for exercise was in line with government regulations, which distance travel, and profession. Reaching out to all types of bicycle use is realistically difficult, although it should be continuously conducted to educate cyclists. Moreover, the Government of the Special Region of Yogyakarta should continuously improve in providing safe and comfortable infrastructures for cyclists. This involved the provision of a bicycle path and routes, safe intersection design, signs, parking areas, and the integration with public transportations. In addition, proper infrastructures indirectly attract the interest of cyclists to use bicycles as their daily mode of transportation. These results are expected to complement several studies on bicycles in Indonesia. Therefore, further studies should be developed through the observation of more effective factors in the bicycle user environment. Several interesting future parameters should be related to the dominant male cyclists, factors causing an accident, or regular cycling interests.

continuously provided information on the importance of immunity and distance maintenance during the pandemic. These results 
supported the government's program in promoting sports activities, based on the regular maintenance of self-immunity (Deniati \& Annisa, 2021). As a sporting tool, the use of bicycles focused on the non-closure of users (Ika, 2020). The number of growing communities was also a forum for the government to socialize in building new habits of cycling, as a means of transportation. This specified that the government should build a safe and comfortable infrastructure for cyclists. As a mode of transportation, the factors affecting the government's decision to convert casual cyclists into regular ones include, (1) building environmental factors (mileage, bicycle parking, road surface quality, and seasonal changes), (2) socio-economic features (age, gender, vehicle ownership), (3) psychological factors (habits, attitudes, norms), and (4) factors related to cost, travel time, comfort, and safety (Heinen, et al., 2010).

Based on the factors affecting cyclists' safety behaviours, this study showed that the regulation scale directly and indirectly affected risk perception and unsafe attitude. Therefore, the government should continue the socialization on road safety rules, with the expectation that cyclists should improve their knowledge and safety behaviors. Future studies is then recommended to focus on experienced accidentbased cyclists, to obtain more significant results. These results were in line with Useche (2018d), regarding the effect of the regulation scale on cyclists' accidents in Europe and Latin America. Furthermore, the knowledge of traffic rules affected safety behaviors when cycling. These results are expected to assist the Indonesian government in making policies regarding the use of bicycles.

\section{DISCLAIMER}

The authors declare no conflict of interest.

\section{AVAILABILITY OF DATA AND MATERIALS}

All data are available from the author.

\section{AUTHOR CONTRIBUTION STATEMENTS}

Danang $F$ and Dewanti conceived of the presented idea. Danang $F$ developed the theory and performed the computations. Dewanti and Imam $M$ verified the analytical methods. Dewanti and Imam $\mathrm{M}$ encouraged Danang $\mathrm{F}$ to investigate a specific aspect and supervised the findings of this work. All authors discussed the results and contributed to the final manuscript.

\section{ACKNOWLEDGMENTS}

The authors are grateful to the bicycle communities in the Special Region of Yogyakarta, for their participation and support in this study.

\section{REFERENCES}

Arifin, M. Z., Wicaksono, A. \& Permata, N. D., 2018. Kajian Strategi Penanganan Program Keselamatan Pesepeda. Malang, Prosiding Simposium Forum Studi Transportasi antar Perguruan Tinggi ke-21 Universitas Brawijaya.

Bike to Work, 2020. https://www.b2windonesia.or.id/. [online] Available at: https://docs.google.com/spreadsheets/d/e/2PAC X-1vTaLpFotxAoQN_ljx3GXkoakMJpesxwSTk3EfQnPD_mpDNzoMKeZn5671M7atI1cdbk7S1D HYqsbi8/pubhtml [Accessed 22 November 2020].

Deniati, E. N. \& Annisaa, 2021. Hubungan Tren Bersepeda dimasa Pandemi Covid-19 dengan Imunitas Tubuh Lansia. Sport Science and Health, 3(3), pp. 125-132.

Ghozali, I., 2008. Model Persamaan Struktural, Konsep dan Aplikasi dengan Program AMOS 16.0. Semarang: Badan Penerbit Universitas Diponegoro.

Haryono, S., 2016. Metode SEM Untuk Penelitian Manajemen dengan AMOS, LISREL, PLS. Bekasi: PT. Intermedia Personalia Utama.

Heinen, E., van Wee, B. \& Maat, K., 2010. Commuting by Bicycle: An Overview of The Literature. Transport Review, 30(1), pp. 59-96.

Ika, 2020. Universitas Gadjah Mada. [online] Available at: https://ugm.ac.id/id/berita/19632- 
pakar-ugm-jelaskan-cara-aman- bersepeda-ditengah-pandemi-corona [Accessed 6 May 2021].

Kementerian Perhubungan RI, 2020. PM 59 Tahun 2020 Tentang Keselamatan Pesepeda di Jalan. Jakarta: s.n.

Kompas.com, 2020. Ramai Pesepeda di Perempatan Tugu Yogya, Bagaimana Penjelasnnya? [Online] Available at : https://www.kompas.com/tren/read/2020/07/12/ 151000165/ramai-pesepeda-di-perempatantugu-yogyakarta-bagaimana-penjelasannya[Accessed 26 November 2020].

Kummeneje, A.-M. \& Rundmo, T., 2020. Attitudes, risk perception and risk-taking behaviour among regular cyclists in Norway. Transportation Research, 69, pp. 135-150.

Lawson, A. R., Pakrashi, V., Ghosh, B. \& Szeto, W., 2013. Perception of Safety of Cyclists in Dublin City. Accident Analysis and Prevention, 50, pp. 499-511.

Mandic, S., Flaherty, C., Pocock, T., Kek, C. C., McArthur, S., Ergler, C., ChilLón, P., Bengoechea, E. G., 2018. Effect of Cycle Skill Training on Children's Cycling-Related Knowledge, Confidence and Behaviour. Journal of Transport \& Health, 8, pp. 271-282.

Ministry of Health of RI, 2018. Directorate of Health Promotion and Community Empowerment. [online]. Available at: https://promkes.kemkes.go.id/content/?p=8807 [Accessed 15 July 2021].

Preacher, K. J. \& Leonardelli, G. J., 2010. Calculation for the Sobel Test. [Online] Available at: http://quantpsy.org/sobel/sobel.htm [Accessed 9 June 2020].

Rundmo, T., 1996. Associations Between Risk Perception and Safety. Safety Science, 24 (3), pp. 197-209.
Sugiyono, 2007. Statistika Untuk Penelitian. 12th ed. Bandung: Alfabeta.

Useche, S. A., Alonso, F., Montoro, L. \& Esteban, C., 2018d. Distraction of Cyclists: How Does It Influence Their Risky Behaviours and Traffic Crashes?. PeerJ Journal, 6, pp. 1-25.

Useche, S. A., Montoro, L. \& Alonso, F. M. T., 2018b. Does gender really matter? A structural equation model to explain risky and positive cycling behaviours. Accident Analysis and Prevention, 118, pp. 86-95.

Useche, S. A., Montoro, L., Tomas, J. M. \& Cendales, B., 2018c. Validation of the Cycling Behaviour Questionnaire: A tool for measuring cyclists' road behaviours. Transportation Research, 58, pp. 1021-2030.

Useche, S., Montoro, L., Alonso, F. \& OviedoTrespalacios, O., 2018a. Infrastructural and Human Faktors Effecting Safety Outcomes of Cyclist. Sustainability, 10 (2), pp. 299..

VicRoads, 2018. A Family Guide to Bike Ed. [Online] Available at: https://www.vicroads.vic.gov.au/safety-androad-rules/cyclist-safety/learning-to-ride [Accessed 19 April 2021].

World Health Organization , 2020. World Health Organization (WHO). [Online] Available at: https://www.who.int/directorgeneral/speeches/detail/who-director-general-sopening-remarks-at-the-media-briefing-oncovid-19---11-march-2020 [Accessed 21 November 2020].

Yogyakarta Government Tourism Office, 2019. DI Yogyakarta Tourism Statistics. Yogyakarta: Yogyakarta Government Tourism Office.

Yunianto, P., 2020. Webinar Keselamatan Pesepeda di Jalan. Jakarta, Kementerian Perhubungan RI. 